\author{
Paulina Sztabińska-Kałowska \\ (1) https://orcid.org/0000-0003-4617-7947 \\ Department of Art History, University of Łódź \\ paulina.sztabinska@uni.lodz.pl
}

\title{
HOW DOES PERFORMANCE AFFECT THE UNDERSTANDING OF 'ART'?
}

\begin{abstract}
The article attempts to discuss some aspects of the impact of performance on the conceptual distinctions concerning art. This issue is very broad, which is why the starting point is the achievements of performers from the 1970s, when the concern with the theoretical context was particularly visible. At the beginning, the views of the participants of the international conference I am organized in Warsaw in 1978 are analyzed, and later texts by Rosalind Krauss and Anne M. Wagner, referring to various activities of Vito Acconci. The article concludes with an attempt to confront the theoretical consequences of sculptures and performances by Robert Morris.

Contemporary attempts at confronting artistic fields may evoke associations with the Renaissance concept of art competition (paragon), but they have a different purpose. The current situation of art is characterized by its indeterminacy. It escapes generalized approaches. However, I believe that an analysis of partial analogies and differences may prove to be an important justification for maintaining the concept of 'art'.
\end{abstract}

Keywords: performance, medialization, role of the audience, comparing arts

Contemporary difficulties in applying the term 'art' are usually considered in terms of general aesthetic or methodology, while in fact they emerge already at the level of the basic nomenclature used when considering specific artistic issues. I would like to partially examine this problem based on theoretical and critical discussions related to performance art of the 1970s, i.e. the era when the concept of such activity was being shaped. At the time, the need to define its relation to the conceptual scope of 'art', as well as to other artistic fields, was more evident than today. ${ }^{1}$ What is, therefore, the status of the word 'art' in the phrase 'performance art'?

1 RoseLee Goldberg links that to the impact of conceptualism. See idem, Performance art. From Futurism to the Present, Thames \& Hudson, London 2001, p. 7. 
In 1978, in the Remont Gallery in Warsaw, an International Meeting of Artists, organized by Henryk Gajewski, was held. The Meeting was devoted to "an attempt at preliminary arrangement of performance issues in terms of their subject matter, history and milieu". ${ }^{2}$ The aim of theoretical presentations and presented actions was to capture the specificity of performance as a new phenomenon in artistic creation. In her introductory remarks, which preceded a publication featuring the materials from the conference, Bożena Stokłosa attempted to signpost fundamental issues that were raised during the session. She drew attention, among other things, to the "great variety of means of artistic expression", "the fact that the artist is present during the execution of the undertaken action, regardless of what role they set for themselves" and the fact that there is a "completely different relationship between them and the audience than when the audience comes into contact just with a work of art." 3 The problem of performance being categorized as part of the field of art was then debated and the presented solutions were usually vague or negative. Either performance was placed between art and life, or it was stressed that artistic references (e.g. performing in art galleries or publishing texts on it in art magazines) do not mean that it qualifies to the same field as works of the past.

Characterizing the "theoretical idea of performance art", Klaus Groh stressed that it is a kind of art, but not one (as in the case of painting or sculpture) that involves an unusual way of showing reality through the work presenting it. Performance "is not outside reality [...] performance is reality," he wrote. It is a reality understood not as a special situation, but as a normal one. "Stupid procedures of everyday life, everyday necessity, are obviously needed, but they are performed by everyone (usually) without realizing their human and aesthetic premises, and thus without recognizing the human aspect of the surrounding everyday life. Performance is not a repetition of everyday life, but a presentation of the structures of everyday activities. They are presented by means of various unusual means of articulation [...]." ${ }^{5}$ The functions of such type of activity indicated by Groh involve 'raising awareness' of what is usually done habitually or by reflex, as well as education and communication. A photographic or film documentation of a performance is also not a work of art in the conventional sense. Groh does not consider this problem to be of much significance. $\mathrm{He}$ believes that performances can be an interesting subject for a photographer or a filmmaker, especially when using a video camera. He even claims that "they

2 B. Stokłosa, "Uwagi wprowadzające", [in:] Performance. Praca zbiorowa, eds. G. Dziamski, H. Gajewski, Jan St. Wojciechowski, Młodzieżowa Agencja Wydawnicza, Warszawa 1984, p. 5. Ibid., p. 10.

K. Groh, "Teoretyczna idea sztuki performance", [in:] ibid., p. 61. Ibid., p. 61- 62. 
are the basic material of video art works. As a consequence, we can say that video-performance is entering the pluralism of today's art forms through live performance ${ }^{6}$. Thus, he treats photographic or video-performances as derivative phenomena that do not affect the way performance art is understood.

Groh placed emphasis on the action, while the performer was treated only as the one who carries it out. Viana de Rosa Conti, on the other hand, emphasized the physicality and personality of the performer. As she posited, "Despite the fact that this action is accompanied by facial expressions, dance, theatre, painting, music, it rejects the script and the written text, it is realized spontaneously in a concrete reality. An actor-artist who uses his/her own body or the body of others, bears the risk and experiences tension, surrendering to chance. This is not about the situation improvised by the artist, but about the threat of interference of reality, updated live from one moment to another in the randomness of events". ${ }^{7}$ In physical and mental terms, therefore, performer is, as in life, exposed to the unpredictable. "The space of the body," de Rosa Conti writes, "transformed into a mediator between the community and nature, finds its magical 'point' and functions as a temple of its own self". ${ }^{8}$

The perception of performance art also has a specific character. "The audience does not participate in the performance as a passive recipient of truth or fiction theater, but becomes a co-participant in a certain 'shred of life' experienced in real time. It overcomes the metaphorical obstruction to enter the metonymic space." 9 The categories of artistic truth and fiction thus lose their meaning. The fictional is not a performance. The viewer becomes a 'co-participant' in the event. Together with the performer, at the same time, he or she experiences a "shred of life". This perception involves different types of receptors and evokes different sensations. "Shifting the emphasis to the living body," writes the author, "the performance is intended to be perceived not only intellectually, but also at the physiological level, with the aim of involving all 'levels' of perception in the audience. Thanks to this, the distance between reality and imagination disappears almost completely. ${ }^{10}$

The situation described above distinguishes performance not only from other performing arts, but also makes it a special cultural phenomenon. As De Rosa Conti puts it, "The 'frontal' relationship with one's own work, characteristic of Western culture, disappears: the artist recovers the 'Bios'. In order to achieve a state of 'total' thinking, he or she refers to the Oriental concept of

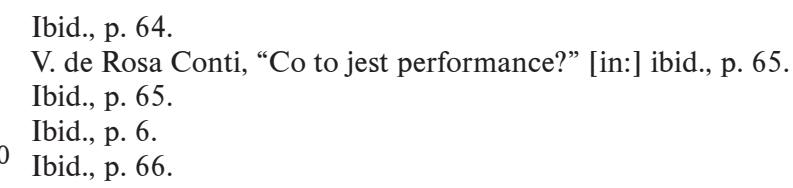


time, captured in the continuity and infinity of its flow." ${ }^{11}$ It can be, therefore, easily assumed that the normal procedures used in other fields of art, such as recoding, reproduction, duplication, etc., do not apply in this case. The ontological specificity of performance makes it impossible to document it. Each form of documentation will impoverish the presented phenomenon, reducing it to showing what is available to one or two senses. Meanwhile, what is "beyond" will remain elusive. Documentation will reduce performance to the level of the "frontal" relation with the work, i.e. the way of perception that is characteristic of traditional art forms. "To sum up," de Rosa Conti writes, "it can be said that in the past, artistic creativity presented a feeling, today it provokes it. The feeling, which was conveyed through form and color, is now realized as a system of action. After the canvas disappears, the form of artistic expression leans towards the spectacle. The virtual and symbolic fact gives way to an event in real time." 12

Sabine Gova also presented the concept of performance as a phenomenon distinct from traditional artistic genres, whose relation to the notion of 'art' is vague. "The traditional approach," she claimed, "is used to define a specific product, a work of art that is easy to compare with other works based on aesthetic norms and expression. They are based on the concept of durability, immovability or timelessness." 13 These terms give the work of art its objective character. Objects of such type have dominated aesthetic thinking and became the basis for the formed concepts. Meanwhile, for many years now there have been ephemeral activities in art, which are temporary and changeable. They "do not aim at objectivity as such, but are realized as events [...]. The duration of an enunciation (event) also means a change in space." ${ }^{14}$ Performance belongs to this group. "The concept of performance", Gova writes, "includes a number of measures such as: acts of behavior, gestures, attitudes, reactions, situations, propositions". ${ }^{15}$ However, unlike other performance theorists, the author does not emphasize the role of the biological factor, the living body, but the conceptual elements. However, she understands their role more broadly than Groh, who reduced them to showing the structure of activities. Gova believes that conceptual factors may consist in confronting the performer's physical activities with other materials, including the media as a means of recording. In the case of performance, she claims, "aestheticism or the beauty of a nude (to put it this way), which possibly presents such an event, does not consist in the

11 Ibid.

12 Ibid., p. 67.

13 S. Gova, "Pojęcie techniki ekspresyjnej zwanej performance," [in:] op. cit., p. 69.

14 Ibid., p. 70.

15 Ibid., p. 69. 
transformation of the body or other medium as a means of expression. It is about revealing the conceptual structures. Therefore, it is not about the domination of aesthetics of form over creation, but rather about the effectiveness of action, especially when testing its 'timelessness' through experience in action." 16 The transient and ephemeral character of a performance is not, therefore, its natural, inherent ontological or aesthetic characteristic, but an object of experience and experimentation. To carry them out, it is necessary to take into account the possibility of making the ephemeral available. Therefore, Gova stresses that such actions may be held directly in front of the public, or indirectly. In the latter case, it is necessary to record them using various materials, such as photographs, slides, films, sound and visual (video) recordings. Therefore, she takes into account documentation that allows to record ephemeral actions. She is aware of the modifications taking place in such a case in relation to the performed action. Therefore, she emphasizes the "function of reporting and providing information" specific to documentation. She refers to the temporary, procedural nature of the performance in question, taking into account, in particular, the change in the environment or the sublimation of the structure. The role of documentary medialization of performance is practical and utilitarian. Thanks to it we can get to know the activity which we could not see directly. It allows you to capture details that would have escaped our attention while watching the action, realize the structure of an event not captured before, and so on. The documentation thus allows the performance to be shown through fixation and reproduction, focusing on "the most important moment(s)." 17 However, as Gova stresses, her role cannot be limited to this. Apart from its practical, in fact passive function, it can play a creative and active role. "In reality," writes the author of the text, "such a record of action introduces certain changes modifying the original situation and potentially provokes new motivations that may lead to the progressive development of new manifestations." 18 Therefore, she does not envisage an autonomous role for documentation (e.g. becoming a separate work of art), but only a service function. Capturing the performance's conceptual structures, which is helped by documenting it, may therefore be important for the active artist. Above all, however, it enriches and deepens the perception, since "media mediation, if it enables a more comprehensible account to be taken of a process that is conceivable in part or in whole in a precise way, develops perception in a broader sense. This way, it causes a real modification of the original vision, starting with a broader awareness of

\footnotetext{
16 Ibid., p. 70.

17 Ibid., p. 71.

18 Ibid.
} 
this phenomenon, which otherwise could only be a manifestation of an attitude that is almost imperceptible or understood in a completely different way." 19

Documentation not only makes it a performance that we have not seen "live" available to us, it does not just broaden the circle of viewers, it is not just a reminder of something that slipped the memory of those who watched the action directly - it interferes with our knowledge of it, enriching its reception. "The interdependence between action and the media used," Gova writes, "can also cause some kind of mutual modification through the simultaneous reception and reproduction. This juxtaposes, or overlaps, or mixes together two different phenomena of perception. This kind of confrontation causes a relative modification or transformation of the homogeneity of time." ${ }^{20}$ Documentation cannot be treated as a side-effect of performance. In the mind of the recipient, it is superimposed on the physical activity itself, intermingling with the latter. ${ }^{21}$ Confronting both types of reception leads to a transformation of the concept of time attributed to performance art.

The three discussed examples of understanding the relationship between performances and their material remains limited the role to documentation. Of course, as I have mentioned, the function has been differently understood and assessed. In the materials from the Warsaw conference I am quoting here, however, there is a text that takes a different approach - it considers the role of the medialization of performance from the perspective of creativity. Vlasta Cihakova-Noshiro entitled it Photo-Performance from Japan, which suggests that this variation of medialization is limited to the country in question only. However, the author presents more general reflections on the variety of art in its general aspect, as well as on other areas of art.

Cihakova-Noshiro starts by stating that the most important issue of performance art at the time of the lecture (1978) is "not the problem of performance itself, i.e. what it is from the point of view of Freudism, phenomenology, personal or social life of the artist, but the relationship between performance and visual experience." 22 This perspective refers to the perception of art, but also to the activities of artists. In this respect, as the author suggests, there are quite unexpected coincidences and differences. One example is the art of

19 Ibid.

20 Ibid, p. 71-72.

21 Twenty years later, I discussed other arguments indicating the necessity of joint consideration of performance and its documentation, formulated by Amelia Jones and Philip Auslander, in my article "Ontologia performansu a performatywność sztuk plastycznych" [Ontology of Performance and Performativity of the Visual Arts], [in:] Dyskursy sztuki. Dyskursy o sztuce, ed. T. Pękala, Wydawnictwo Uniwersytetu Marii Curie-Skłodowskiej, Lublin 2018, p. 103-113.

22 V. Cihakova-Noshiro, “Foto-performance z Japonii”, in: op. cit. p., 83. 
soil, where soil and other large-sized natural elements were used in locations outside the gallery. The works, on the other hand, were "essentially communicated through new visual means (photographs, $8 \mathrm{~mm}$ camera, video tape) in the form of images." ${ }^{23}$ Of course, these were not images 'in and of themselves', but rather documentation. However, the vastness of the problem of imaging has been realized. When using similar formal means, its character could be treated as different. What ensued was, as the author writes, "a conceptual expansion of painting and sculpture. This expansion was achieved through the use of new media." ${ }^{24}$ Challenging the traditional fields of art, performance entered into a dialogue with them. It took place on the level of acceptance of a similar communicative situation. "Despite all its freedom and identity," Cihakova-Noshiro writes, "performance needs viewers and, consequently, visual media. It is said that the importance of media is obvious, but they are completely subordinated to the sense of the action or the performance itself. I don't agree with that. The existence of performance is undeniable as long as it considers itself to be art, specifically visual art. And if it is (visual) art, then it cannot exist without analyzing and solving problems of (visual) art by means of communication media." ${ }^{25}$ The mediality of performance did not appear at a certain point in its development, nor can it be considered characteristic of certain artists or varieties of this type of art. The issue of documentation belongs to the essence of performance. It is only possible to analyze what kind of preferences we are dealing with in the case of its different varieties.

Thus, Cihakova-Noshiro distinguishes between two opposing types of performance. The first one is a kind of "pure experience". In such cases, the impact is multisensory, involving a multitude of sensory responses, as is the case in everyday life. However, even then (as can be seen in Stelarc, Petr Štemberg,

23 Ibid.

24 Ibid. The author believes that this problem did not occur in the 1950's and 1960's in connection with happenings and events because they did not create any proper visual means. They were chains of events, or single events realized by all participants. This collective character meant that there was no difference between the performers and the audience. The issue of communication was therefore limited to the interaction between participants of a given event. "A happening," Cihakova-Noshiro writes, "did not require any specific measures; it contained many improvised, unforeseen actions and an unpredictable randomness. It was not only the positive spect of the happening, but also its weakness. For without any conventional form of expression or any visual means of expression, a 'happening' blended into everyday social life, becoming a journalistic term for a completely free attitude, liberated from social conventions" (ibid., p. 84). It was similar in the case of events that showed 'things' in relation to space, situation or body and thus revealed the artist's attitude towards art. "Most of these events, due to their vague role as art document and the lack of their own visual means, remain unrecorded, and are not considered works of art (ibid., p. 84). 
Marina Abramovič and Ulay or Gina Pane) there is a tendency to carefully prepare visual documentation. However, a different kind of experience and media concept emerges. The author understands the word "media" broadly and identifies it with "technical measures", such as the conceptual quotation of materials, the combination of means of expression through the inclusion of drawing, photography and the combination of words and images. This leads to the presentation of the performance "in the visible and illusory world of the media" ${ }^{26}$. Cihakova-Noshiro points out that this leads to a shift in the problem of performance. If in the former case, the 'action' is essential (the body of the artist and his/her activity) as well as its "observation", the latter, due to the fact that the role of the media is taken into account, is a combination of 'action' and 'observation'. Explaining this problem, the author writes: "We can therefore distinguish between 'active performance' and a kind of 'media-performance' which leads us to a sense of a certain illusionism based on the analysis of 'observation' through media/means, or to a completely new fictional space of subjective or psychological spiritual experience." ${ }^{27}$ This should probably be understood as meaning that the "active performance" is characterized by a peculiar materialism consisting in emphasizing the value of direct contact with the artist's body, together with all the complex ways of its manifestation, perceived through different senses. In the latter case, the number of stimuli is limited. In the case of photography -to one or more selected body positions, without any sound, smell, etc. effects. In the case of a film or video, movement changes and possibly sounds are taken into account, but the remaining stimuli are eliminated. This can be seen as a limitation of documentation as compared to the direct contact with the active artist. However, it can also be assumed, as Cihakova-Noshiro points out, that this is a new opportunity for performance. She describes it as "neo-Romanticism" (claiming that the name is predominantly used in Europe) or a 'photo-object', as it is usually called in Japan. In both cases, photography is involved "to create a newly conceived 'object,' whose quality, as a performance, is determined by the new properties of the media used and its operative selection." ${ }^{28}$ The 'object' presented in the photograph is obtained using physical-chemical means. In this case, the properties of the medium are used to "reproduce within the scope of production, the ability to make material things immaterial, to make illusion an anti-illusion in its essence, to create fiction by nonfictional means, etc." 29

26 Ibid.

27 Ibid., p. 86.

28 Ibid.

29 Ibid. 
I began this article by presenting and commenting on four theoretical texts from 1978, as they feature different attitudes towards performance and the possibility of its medialization. There are also different ways of locating the live action in relation to the components or products in question. Groh, recognizing that the multimedia nature of performance is a consequence of its relationship with the everyday life of a human being, stated that documentation is in fact a new work created on the basis of the observed activity. However, he did not determine its relation to art. De Rosa Conti described performance as 'experiencing existence' - not fiction, not a show - and on this basis she distinguished it from other areas of art where reality is virtualized. That is why, in her opinion, it is in fact anti-media in nature, and its medialization negates performativity. Gova emphasizes the specificity of performance, although she places it within the framework of art. Its ephemeral and transient character should therefore be considered as an area of experience and experimentation, in which media recordings can also be involved. Documentation makes the analysis of performance possible, helps to understand it, grasp its conceptual structures, but it can also be a starting point for modification of the 'original vision' and taking into account what may not be incidental to the action itself, but is not the same as the action. Cihakova-Noshiro was in favor of the closest and farthest-reaching relationship between performance and media. Performance, in her opinion, is a visual art, but its problems cannot be limited to the aesthetic and therefore must be solved in connection with 'communication media'. She suggested that apart from considering the relationship between 'action' and 'observation', the possibility of combining 'action' and 'observation' should be taken into consideration, and this could be achieved in "media-performance". Evident in each of these concepts is, on the one hand, a desire to take performance beyond art, to demonstrate that it belongs in an equal, or perhaps even larger measure to the area of life, that it does not fall within the genological categories of art, not to mention aesthetic functions it is traditionally attributed. On the other hand, in their analyses, the authors take artistic categories, and not only issues of life (e.g. problems of psychiatry, communication, sociology of everyday life, etc.), as a point of reference. This results in a specific situation described by the researchers of the 20th century avant-garde as 'non-art' or 'postart', in which there is an aspiration to go beyond the artistic field, albeit without losing contact with it. This contact could be biographical (related to education and previous activity) or conceptual, and consist in the inability to break away from the notion of 'art'. ${ }^{30}$ Another issue that may be a consequence

30 This issue was analyzed by Grzegorz Sztabiński in his closing book Inne idee awangardy. Wspólnota, wolność, autorytet, Wydawnictwo Neriton, Warszawa 2011. 
of the one mentioned above is the relationship between documentation and work. There are also complex interdependencies in this respect. On the one hand, the creators of performances from the 1970s wanted to make documentation fully dependent on the action. They rejected the notion that it might operate independently, like works of visual art or literature, but on the other hand they felt that its performance was not only an opportunity for the event to survive in the memory of the audience, or a chance to inform about it more broadly, but also that a new quality appeared along with it. As a result, some feared that should the entirety of documentation be handed over to another person (photographer, filmmaker), it would deprive them of control over that part of the performance understood as a whole. Therefore, they tried to control the documentation process by affecting its formation in different ways. In the end, the best solution proved to be making documentation inseparable from the performance.

Anne M. Wagner examines one of the best-known examples of such an approach, namely the famous action by Vito Acconci Following Piece. ${ }^{31}$ She begins her article quoting the view of the 18th century French writer JeanFrançois Marmontel, who wrote that art requires witnesses. He only excluded music from this principle, as it can be enjoyed by the performer on his or her own. For what reasons did the author exclude witnesses from his action and did he actually exclude them? From 3 until 25 October 1969, he followed the same, strict 'daily pattern' which depended on choosing a random person in the street, whom he then followed until they entered somewhere he had no access to (e.g. their own home, office, etc.). This activity is often treated as an example of a completely private performance that excludes the participation of the audience. It seems that it takes place without witnesses and constitutes the artist's private experience. However, we have photographs of him. Betsy Jackson, who followed Acconci as he was tracking selected people and photographed the emerging situations, was a witness. When we take into account her presence, two people in the situation under consideration (the follower and followed) turn out to be three. The number grows to four, when we realize that any passer-by could notice that someone is following someone else, and these situations are photographed by yet another person.

How does this situation take on a visual form? It seems that is not so much the role of the active artist or other people taking part in the event as that of the camera that is crucial. It is for the camera and around the camera that everything is happening. ${ }^{32}$ In order to discuss this issue in more detail, Wagner

31 A. M. Wagner, Performance, Video, and Rhetoric of Presence, "OCTOBER" 2000, no 91.

32 Analyzing the photographs, Martha Buskirk pointed out that the process of following the people chosen by Acconci took into account the fact that the pictures were taken. The action is 
also referred to Acconci's another action, carried out in 1971, entitled Centers. During the performance, the artist held a video camera for 22 minutes and 15 seconds, directed at himself. His fingers twitched involuntarily, his shoulders slumped when he grew tired, but he tried to maintain his initial posture all the time. This work has been thoroughly analyzed by Rosalind Krauss. Because of the importance of the issues raised therein, aside from the interpretation presented by Wagner, I will also take into account other issues in her article.

According to Krauss, what distinguishes Centers from other performances is the focus on the relationship between the artist and the recording mechanism. While other performers performed in front of the audience and the documentation was an accompanying element, here the only option for the viewers to access the artist's action was by watching it on a monitor. Executing the project without the participation of the person documenting it was possible thanks to the invention of video technology, where the camera can be operated by the performer him/herself. That is why Krauss believes than Centers is a kind of critical attack on the logic of the medium. Acconci used video as a mirror - his gaze and gesture shown in the center of the monitor indicated that he was looking at himself. The author interpreted the work as a kind of tautology, since the line of sight ran from Acconci's eyes to his double appearing as a projection.

Krauss considered this situation characteristic not only of Acconci's use of video, but also of the new medium in general, and described it as "the aesthetics of narcissism." "In that image of self-regard is configured a narcissism so endemic to works of video," Krauss wrote, and added that she wanted to generally recognize it "as the condition of the entire genre." ${ }^{33}$ This narcissism was treated as "a psychological rather than a physical condition". ${ }^{34}$ This meant that she treated psychology not only as a determinant of the use of means of expression, but also as a subject of her works. She assumed, therefore, that the appearance of video in the field of performance art would cause changes in the functioning of the recorded activities. In her opinion, video as a medium differs from a medium such as painting, sculpture or film, which "has much more to do with the objective, material factors specific to a particular form: pigment-bearing surfaces; matter extended through space; light projected through a moving strip of celluloid. That is, the notion of a medium contains the concept of an object-state, separate from the artist's own being, through which

therefore a camera-like one. In addition, Acconci developed a strict action plan reminiscent of the conceptual works of Sol Le Witt (cf. The Contingent Object of Contemporary Art, The MIT Press, Cambridge Massachusetts, London 2003, p. 217.)

33 R. Krauss, Video: The Aesthetics of Narcissism, “OCTOBER” 1976, nr 1, p. 50.

34 Ibid., p. 50. 
his intentions must pass." ${ }^{35}$ In the case of a video recording made by the performer him/herself, there is no materiality of the medium, and the performer looks at him/herself in their own reflection on the monitor as in a mirror or on the surface of water. There is no need for another person to record it, no need for spectators during the performance of the action. Thus, are we dealing with bringing performance closer to the process of painting a self-portrait?

The invention of video, as Krauss pointed out, could pose a as it was now possible to perform the action in front of the camera on one's own, while the image of the artist was immediately watched on the monitor. Under such circumstances, the audience could only see the effect of a situation that was not directly available to them. The presence of an artist as a physical person, so important in the concepts of performance art, is, so to speak, put into parentheses. According to Krauss, the video performance Centers was meant to exemplify self-absorption and hermetic sealing of the body between two machines: a camera and a monitor. Instead of a free-acting performer, there was a situation of restriction, analogous to placing a fragment of a sentence in between parentheses.

'Self-absorption' and the 'hermetic' nature, indicated as a result of media involvement in the process of the performer's activities, require more consideration. What does placing a fragment of a text between parentheses involve? It separates a certain number of words from the main line of the argument, thus making them incidental. Applying such an approach to the characteristics of performance, one can say that the conscious use of a video camera and monitor by the performer creates a similar effect. If performances, as many of their authors have maintained, are linked to life, to the experience of existence, and are not specially designed shows, then the introduction of a new recording apparatus has changed this situation. Some actions that started when the recording began and ended when the recording device was switched off were isolated. The role of reference to the audience was replaced by watching one's own image on the monitor. This is how I understand the analogy between the role of parentheses in a sentence mentioned by Krauss. The author, however, derives further-reaching consequences from this situation, accusing the medialization of performance of narcissism, as well as of "self-absorption" of the artist's action and hermetic sealing.

Are these allegations correct? They are usually justified by the accepted concept of performance as a field open to the outside world, whose constitutive feature distinguishing it from the painter's actions is the direct contact with the audience. Acconci's Centers, on the other hand, is more reminiscent of painting or drawing self-portraits, although at the same time it differs from those activi-

35 Ibid., p. 52. 
ties in many ways. Thus, we are dealing with an achievement that significantly affects our understanding of art, disrupts the existing borders and makes us rethink them. As a result, both the concepts of performance and self-portrait are no longer indisputable. Referring to the comparison used by Krauss, Wagner points to another possibility of interpreting the situation arising in the case of video performance. She believes that instead of writing about parentheses, one could refer to the key poetic figure of apostrophe. It involves ostensibly turning away from the audience and addressing some dead or absent, a deity, a thing, or an abstract idea. This leads to a tactical suspension of the communication process, but not to its closure and separation from the external. Wagner accuses Krauss of adopting a strategic stance in which the performance Centres acts as a handy example to show that "camera and monitor make the man and his gesture quite literally parenthetical to her line of thought." ${ }^{36} \mathrm{Her}$ own position is more moderate and assumes that "'parentheses' only apparently enforce a closure: the technology of the monitor opens outward, as well as in. Not only does it register a process of surveillance, it itself asks for monitoring." ${ }^{77}$ The fact that performance enters into various contexts of issues important from the point of view of theory is particularly evident when taking into account its intersecting or overlapping with visual arts. While Wagner is not particularly concerned with the issue in her article, the author nevertheless discusses interesting examples that allow us to draw conclusions on that subject. Their starting point is a generally understood presence in a space, in which people and their images appear simultaneously. Presence is a key concept for performance theory. In order to achieve the effect of its doubling, photographs, film images, cameras and video monitors as well as mirrors were used. For example, mirrors appeared in Joan Jonas' 1970 performance, reflecting the seated audience, whose relationship with the performing artist became more complex. Another example is Dan Graham's action Performer/Audience/Mirror performed and recorded in various versions in 1975-77. It was aimed at engaging the audience in a carefully observed description of what was taking place. The performer stood in front of the audience, and behind his back there was a mirror, in which the audience could see themselves. "His descriptions are profoundly trivial," Wagner wrote, "they detail coughs and fidgets, coats being doffed and glasses polished - but they still serve to summon and produce the audience as both a whole and a collectivity of parts. Meanwhile the artist's relentless patter produces and enforces a continuous present for the duration of the piece." 38 Another example of an action based on a 'mirror' play with the audience was

\footnotetext{
36 A.M. Wagner, op. cit. p. 68.

37 Ibid.

38 Ibid., p. 71.
} 
Acconci's 1969 Performance Test. The artist simply looked at individual participants sitting opposite him and ordered them to change places - from left to right, from front to back in thirty seconds. During those sequences, the game of the optical vicious circle between the performer and the audience began. Acconci made eye contact and then transferred his gaze to someone else: "Audience looks at performance, performance looks back at it-the gaze of the audience results in nothing, is turned back on itself. ${ }^{39}$ There is no mirror, no video camera, no monitor, and yet there is a mirror effect. What should be emphasized is that it lacked the moment of narcissism, which appears in individual variations in other performances.

Robert Morris's 1965 work Untitled (Mirrored Cubes) seems to be the most appropriate sculptural point of reference for these activities. The installation consists of cubes made of laminated Plexiglas, creating a mirror effect. They were placed in galleries, or in external spaces, reflecting the changing environment. With the clear materiality of objects and the simplicity of their shape, they were characterized by their complexity from the perceptual point of view. In reference to them, Morris wrote about sculpture 'beyond objects'. "If one notices one's immediate visual field, what is seen?" he asked. "Neither order nor disorder. Where does the field terminate? In an indeterminate peripheral zone, none the less actual or unexperienced for its indeterminacy, that shifts with each movement of the eyes. What are the contents of any given sector of one's visual field? A heterogeneous collection of substances and shapes, neither incomplete nor especially complete (except for the singular totality of figures or moving things)." 40

I believe that these remarks can be applied both to Mirrored Cubes and to the performances discussed above. In both cases, it is not clear where the visual field begins and ends, where the main zone is located and where the peripheral zone is, whether it is real or not, and whether it shifts with each movement of the eyes. Such effects can, as demonstrated by the examples of Graham's performance and Morris' sculptures discussed above, be achieved through the use of mirrors and additional object factors, but a 'visual field' can also be achieved through a 'mirror effect' without a mirror. From this point of view, the action Performance Test carried out by Acconci is particularly interesting. As Wagner wrote, "What separates video and performance from the effects set in motion by Morris's mirrored cubes? Not, I think, their desire to deploy or manipulate their viewers; this is something all these media share. The difference involves a new admission of worry about how and if such a relationship might still be

39 Ibid., p. 73.

40 R. Morris, Notes on Sculpture IV: Beyond Objects, "Artforum” April 1969, quoted in http:// theoria.art-zoo.com/notes-on-sculpture-4-beyond-objects-robert-morris/ 
engineered. And it entails an anxiety about the publicness of such encounters urgent enough to summon the artist out from 'behind' the work to stand or act in its place." ${ }^{11}$ As we know, after 1962 Morris undertook action in the field of performance. As he wrote about them in 1965, "By the uses of objects which could be manipulated I found a situation which did not dominate my actions nor subvert my performance. In fact, the decision to employ objects came out of considerations of specific problems involving space and time. For me, the focus of a set of specific problems involving time, space, alternate forms of a unit, etc., provided the necessary structure." 42 Thus, the artist's coming out from 'behind' the work was not motivated by narcissism, nor did it lead to it. On the other hand, it introduced new ingredients to becoming a public work. RoseLee Goldberg points out that the nature of Morris' performances was affected by dance and abstract Expressionism painting, from which the artist began his career. She wrote "that a sculptor like Morris created performances as an expression of his interest in the 'body in motion'." 43 This body in motion, however, was not meant to be something separate, but an important structural element connected with visual works. Thus, performance was treated not as something opposite to the object system (a visual artwork), but as a link to it. It also drew attention to the dangers of the reification of a work of art and its stabilization. Goldberg writes that in contrast to his earlier task-oriented activities, the artist wanted to be able to manipulate objects so that they did not dominate and 'overturn' the meaning of the physical performance.

Thus, one can say that sculpture and performance art are mutually illuminated, that comparing them allows both artists and art theorists to see features not taken into account beforehand. This contemporary form of rivalry is not akin to the Renaissance art competition (paragone), and its purpose is also different. The conceptual categories characteristic of particular artistic fields taken into account in this paper indicate that although the contemporary area of artistic phenomena is, to a large extent, undefined, not subject to generalizing approaches, we are dealing with partial albeit important analogies and differences within its area. They are taken into account by artists. Perhaps they should also become more of an object of interest for art critics and theoreticians. Such analyses would point to the need to refer not so much to the general notion of 'art' as to its specific subranges.

I started this article by discussing the effect of performance on the conceptual distinctions concerning art adopted in the 1970s. The associated boundaries were questioned by most of the significant neo-avant-garde directions of

\footnotetext{
41 A. M. Wagner, op. cit. s, 73-74.

42 R. Morris, Notes on Dance, "The Tulane Drama Review" Vol. 10, No. 2, Winter, 1965, p. 180.

43 R. L. Goldberg, Performance Art..., op. cit., p. 141-142.
} 
that era. The divisions between art and life, between material, visual and conceptual activity, between work and documentation, etc., were blurred. This led to a situation in which the creator ceased to be a specialist in a specific field, and by taking the side of life he or she became involved in the current problems of contemporary times. In this respect, the impact of performance on art was particularly extensive. Its representatives often did not even define themselves as such, but used the term 'artist' instead. These tendencies have influenced the way in which reflection on art is practiced, contributing to the conviction that there is no point focusing on comparing works of art with respect to their belonging to specific disciplines, but rather their involvement in current social or political trends should be taken into account. Since the concepts of painting, sculpture and performance have become vague, it is not worth analyzing them. In this article I wanted to show that comparisons that include certain aspects of art theory may be interesting, even though they do not lead to the formulation of a general theory.

\section{BIBLIOGRAPHY:}

Buskirk Martha (2003) The Contingent Object of Contemporary Art, Cambridge Massachusetts, London: The MIT Press.

Goldberg RoseLee (2001) Performance art. From Futurism to the Present, London: Thames \& Hudson.

Krauss Rosalind (1976) Video: The Aesthetics of Narcissism, „OCTOBER”, no. 1.

Morris Robert (1965) Notes on Dance, „The Tulane Drama Review” Vol. 10, No. 2, Winter, pp. 179-186.

Morris Robert (1969), Notes on Sculpture IV: Beyond Objects, „Artforum” April, http://theoria. art-zoo.com/notes-on-sculpture-4-beyond-objects-robert-morris/

Performance. Praca zbiorowa (1984) Dziamski G. Gajewski H., Wojciechowski J. St. (eds), Warszawa: Młodzieżowa Agencja Wydawnicza.

Sztabińska-Kałowska Paulina (2018) Ontologia performansu a performatywność sztuk plastycznych, in: Dyskursy sztuki. Dyskursy o sztuce, ed. T. Pękala, Lublin: Wydawnictwo Uniwersytetu Marii Curie-Skłodowskiej, pp. 103-113.

Sztabiński Grzegorz (2011) Inne idee awangardy. Wspólnota, wolność, autorytet, Warszawa: Wydawnictwo Neriton.

Wagner Anne M. (2000) Performance, Video, and Rhetoric of Presence, “OCTOBER”, no. 91 


\section{JAK PERFORMANS WPŁYWA NA POJMOWANIE „SZTUKI”? (streszczenie)}

W artykule podjęta jest próba omówienia niektórych aspektów wpływu performansu na rozróżnienia pojęciowe dotyczące sztuki. Zagadnienie to jest szerokie, dlatego punktem wyjścia są dokonania performerów z lat siedemdziesiątych XX wieku, gdy uwrażliwienie na kontekst teoretyczny było szczególnie widoczne. Na początku analizie poddane zostały poglądy uczestników zorganizowanej w 1978 roku w Warszawie międzynarodowej konferencji I am, a później nawiązujące do różnych działań Vito Acconciego teksty Rosalind Krauss oraz Anne M. Wagner. Artykuł kończy próba konfrontacji teoretycznych konsekwencji rzeźb i performansów Roberta Morrisa. Współczesne próby konfrontacji dziedzin artystycznych mogą wywoływać skojarzenia z renesansową koncepcją współzawodnictwa sztuk (paragone), ale mają inny cel. Aktualna sytuację sztuki cechuje nieokreśloność. Nie poddaje się ona generalizującym ujęciom. Uważam jednak, że analiza częściowych analogii i różnic może okazać się istotnym uzasadnieniem utrzymywania pojęcia „sztuka”.

Słowa kluczowe: performans, medializacja, rola publiczności, porównywanie sztuk

Paulina Sztabińska-Kałowska - PhD, associate professor in the Department of Art History, University of Łódź, lecturer at PWSFTviT in Łódź. Winner of the Jan Józef Lipski award for best MA thesis (2003) and the Szczęsny Dettloff award for best doctoral dissertation (2008). Author of the books: Geometria a natura. Polska sztuka abstrakcyjna $w$ drugiej polowie XX wieku [Geometry and nature. Polish abstract art in the second half of the twentieth century], Warszawa 2010 and Sztuka geometryczna a postmodernizm [Geometric Art and Postmodernism], Warszawa 2011. Co-author and co-editor of the book The proper names in the art of Łódź. Contemporary painting, graphic arts, sculpture and intermedia, Łódź 2008. Editorial associate of the journal Art Inquiry. Recherches sur les arts. Her research interests focus on the twentieth century art and art theory. 